Discourse and Communication for Sustainable Education, vol. 7, no. 1, pp. 23-36, 2016

\title{
Do Environmental Education School Coordinators Have a Mission?
}

\author{
Petra Šimonová and Jan Činčera \\ Masaryk University, Brno
}

\begin{abstract}
Teachers who are specialized in environmental education (environmental education school coordinators ${ }^{1}$ ) can play an important role in empowering students to shape a sustainable future. In this study, the authors examined a group of Czech environmental education school coordinators. The authors aimed to clarify how they interpret their role at their respective schools, how they perceive their self-efficacy, and what they observe as benefits and barriers to their work as a coordinator. They conducted a qualitative study with focus groups and completed individual in-depth interviews with the coordinators. The results suggest that the coordinators view their work as a mission. The ultimate goal of this mission is to change the children's behavior to make it more pro-environmental, and, at the same time, to establish this effort as a commitment of the whole school. The authors identified different forms of mission, described development in time and connected them with the perceived self-efficacy of the coordinators.
\end{abstract}

Keywords: environmental education, EE school coordinators, teacher training, teachers' self-efficacy

The authors believe in the crucial role of environmental education (EE) in changing society to become more sustainable. Moreover, they consider the role of teachers in changing students' behavior to be indisputable. The school is, therefore, one of the most important playgrounds for providing high-quality EE (Raus \& Falkenberg, 2014; Pipere, Veisson \& Salite, 2015). EE is an interdisciplinary and quite a complex field, which means that teachers have to link the methods and content of the natural and social sciences, the arts, mathematics, and humanities to address complex environmental issues. They also need to cope with the notion of attitudes and values in the context of proenvironmental behavior (Świtala, 2015). Teachers should also acquire a certain level of environmental literacy and understand EE thoroughly, as well as develop specific skills to put EE into practice (Simmons, 2010). Unfortunately, in many countries, teachers' pre-service training does not include more than a basic environmental awareness; fortu-

${ }^{1}$ Environmental education school coordinators are specialized teachers, who decided to plan, organize and perform environmental education at school in Czech Republic. 
nately, the knowledge gap is reduced by several in-service training courses mostly provided by environmental centers (Kyburz, Graber \& Robottom, 1999).

A well-prepared EE training program should develop the knowledge, skills and attitudes that would help teachers plan, coordinate and implement EE. Teachers should also be trained in teamwork to be able to integrate EE into the curriculum in cooperation with their colleagues (Van Petegem, et al., 2005). May and Flack (2001) emphasize the flexibility of teacher training because teachers must be able to choose appropriate teaching strategies according to the changing environment. However, some research shows that no kind of training has the power to improve EE teachers' effectivity, as measured by student achievement if their EE efforts are not sufficiently adapted to the specific school context (Harris \& Sass, 2011).

Positive attitudes to $\mathrm{EE}$ and the willingness to practice $\mathrm{EE}$ at school cannot be guaranteed solely by the training but develop gradually in the course of one's teaching practice. One of the important measures of motivation for the implementation of EE is the teachers' perceived self-efficacy (Moseley, Reinke \& Bookout, 2002). The self-efficacy concept has been investigated by a number of studies (Bandura, 1977; Dembo \& Gibson, 1985; Evans \& Tribble, 1986; Evers, Brouwers, \& Tomic, 2002; Khan, Fleva, \& Qazi, 2015; Reilly, Dhingra, \& Boduszek, 2014); even so, it remains open to further research, especially in the EE context.

Practicing good quality EE at school also entails creating an environmentally friendly school culture and changing not only the educational perspective but also the organizational and governance practices (Schelly, Cross, Franzen, Hall, \& Reeve, 2012). The teachers' behavior, as well as the ways in which they discuss the topic with colleagues at their school, has the capability to serve as a very effective model for students' attitudes and behavior (Higgs \& McMillan, 2006).

\section{EE School Coordinators in the Czech Republic}

Teachers in the Czech Republic still benefit today from the advantages rooted in the strong support for EE established in the 1990s by the Government; numerous environmental centers were founded and EE was incorporated into the educational system as a cross-curricular subject (CENIA, 2015). The Ministry of Education has issued instructions on how to implement environmental education into the schools and officially established the role of EE school coordinators (MSMT, 2008). It was mandated that the training for EE school coordinators be conducted according to defined standards and include 250 hours of direct instruction. Training includes three basic pillars of the school EE curricula: planning, coordination and implementation of the cross-curricular subject activities. Teachers should be inspired by "best practices" examples at various schools and environmental centers. Ultimately, EE school coordinators are expected to develop a long-term vision and action plan for the $\mathrm{EE}$ at their individual schools. Establishing the role of the EE school coordinator and mandating 250 hours of direct instruction is quite unique within the European academic arena. Therefore, this specific Czech situation opens great possibilities for various research inquiries focused on the establishment of the EE.

The EE school coordinators' training has been evaluated in two qualitative studies (Činčera, 2013; Činčera, Gilar, \& Sokolovičová, 2010) which found, on the one hand, a high satisfaction with the training, but, on the other hand, poor understanding of EE goals as well as cognitive dissonance between the teachers' initial concepts of EE and 
the concepts presented in the training. There is still a lack of understanding of the teachers' views of different EE concepts and especially of the development of the EE school coordinators' role during the years after completing the training.

The authors aimed to understand the long-term impact of the environmental educators' training on the EE school coordinators' teaching practices. We want to clarify how they interpret their role at their respective schools, how they perceive their self-efficacy, and what they observe as benefits and barriers to their work as a coordinator. This study provides a unique opportunity to study this phenomenon in the European context because no other European country has such a long and high developed training for environmental educators. The results will help us to understand the crucial elements of the quality of the EE at schools (dealing with the complexity and changeability of EE, linking to the school culture, etc.). Therefore, the authors set the following questions:

What kind of changes does the training make in the long-term practice of EE school coordinators?

How do teachers interpret their role and the changes in their practice after completing the training?

How do teachers perceive and evaluate their self-efficacy as environmental coordinators?

What are the benefits and barriers to teachers' work as school coordinators?

\section{Methodology}

The authors conducted the study with 12 teachers from 12 Czech elementary schools during the summer and autumn of 2014. They used the qualitative methodology and collected the data in two stages. During the first stage, one of the researchers conducted three focus-group interviews. Each interview took approximately 60 minutes. In the second stage, four individual interviews were conducted with some of the participants in hopes to gain a deeper insight into the opinions of the teachers and to address a need for clarification that had arisen after the focus groups interviews. This second part of the research was added during the analysis of the focus groups interviews; however, because no further insights accrued, it was ended after four interviews. The individual interviews took approximately 40 minutes.

Both stages of interviews were semi-structured with pre-prepared questions so that the participants were able to add questions and reactions during the conversation. As the authors conducted the research within the frame of constructivist grounded theory (Charmaz, 2006), we used open questions and allowed the teachers to truly express their opinions. During the focus-group interviews, we focused on several themes; for example, the authors asked about their reflection of changes after the training course, about the EE concept, practical EE application, and/or about the perceived role of the EE coordinator. In individual interviews, they used similar themes, but with an emphasis on deeper understanding. They also added a question that focused on perceived achievement with respect to the coordinator's role. They asked all the respondents for their approval to record the interviews, and we informed them about the ways we planned to use the data.

The twelve participants were Czech elementary school teachers who had completed a 250-hour training for EE coordinators in the school years 2008-2009 and 2009-2010. We invited fifteen graduates who attended the in-service course in the school year 2013-2014. Additionally, they asked to participate other twenty former graduates, who still worked as EE school coordinators. Unfortunately, only twelve teachers were 
finally willing to participate. The three focus groups were divided according to the calendar year they attended the course. The authors asked nine teachers (three from each focus group) to let us interview them individually, and six of them agreed. They chose teachers from different school contexts to obtain more diversity in the conversations. After four interviews, they identified theoretical saturation of the data, and in accordance with the tenets of Grounded Theory (Strauss \& Corbin, 2008), decided not to continue with the other interviews.

One of the researchers conducted all the interviews and was also the chief instructor in the training as well as the in-service course. She spent more than 500 hours with the teachers during the training. She came to know the teachers quite well, so the atmosphere during the interviews was relaxed and the teachers felt free to answer honestly. This familiarity with the training and also with the teachers helped in identifying key aspects during the data analysis. On the other hand, such familiarity could be a source of bias.

\section{Data analysis}

The authors transcribed the recorded conversations and analyzed them according to the grounded theory approach. They began with initial coding: we did not code exactly line by line but used a logically connected data section of an appropriate length per code (Šed'ová \& Švaríček, 2007). After the first coding level, they clustered the data and reviewed the clusters to create tentative category names with an emphasis on process. Finally, they used theoretical coding to identify the central category and linked the data to a new story line (Saldana, 2009).

\section{Results}

During the second cycle of the coding process, we identified 14 categories which include all the coded data. The categories describe the processes articulated by the study participants and are closely related to the research questions (Table 1).

Table 1

Thematic Coding Categories

\begin{tabular}{|c|c|}
\hline Research question & Coding categories \\
\hline 1 & 2 \\
\hline $\begin{array}{l}\text { What kind of changes does } \\
\text { the training make in the } \\
\text { long-term practice of EE } \\
\text { school coordinators }\end{array}$ & $\begin{array}{l}\text { defining environmental education } \\
\text { practicing EE } \\
\text { setting EE goals } \\
\text { assessing course benefits } \\
\text { reviewing the coordinator's self-development (Before-After-Later) }\end{array}$ \\
\hline $\begin{array}{l}\text { How do teachers interpret } \\
\text { their role and the changes } \\
\text { in their practice after } \\
\text { completing the training? }\end{array}$ & $\begin{array}{l}\text { perceiving the coordinator's role } \\
\text { practicing EE in the school context } \\
\text { dealing with pupils } \\
\text { EE teaching strategies }\end{array}$ \\
\hline $\begin{array}{l}\text { How do teachers perceive } \\
\text { and evaluate their self- } \\
\text { efficacy as environmental } \\
\text { coordinators? }\end{array}$ & $\begin{array}{l}\text { evaluating success by } \\
\text { judging self-esteem } \\
\text { evaluating self-efficacy } \\
\text { reviewing the coordinator's self-development (Before-After-Later) }\end{array}$ \\
\hline
\end{tabular}


Sequel to Table 1

1

What are the benefits and barriers to teachers' work as school coordinators?

practicing EE in the school context relating with colleagues

establishing relationships with the school leadership

The authors described the relationship between these categories and developed the story line summarizing the key findings (see Fig. 1): "The development of the coordinator's mission (before the course - after completing the course - in long-term practice)". The description of the main categories follows:

\section{The EE Coordinators' Mission}

All the identified categories are linked to the central category: the EE coordinators' mission (see Fig. 1). The authors established a working definition of this central category as the coordinators' commitments combined with their perceived roles, expected goals and the ways to achieve them. The core of the mission is seeing EE as a crucial element in education. The coordinators believe that it is important to change the children's behavior to be more pro-environmental and, at the same time, require that the whole school work toward achieving this goal.

The development of the coordinator's mission

(before the course $\rightarrow$ after completing the course $\rightarrow$ in long-term practice)

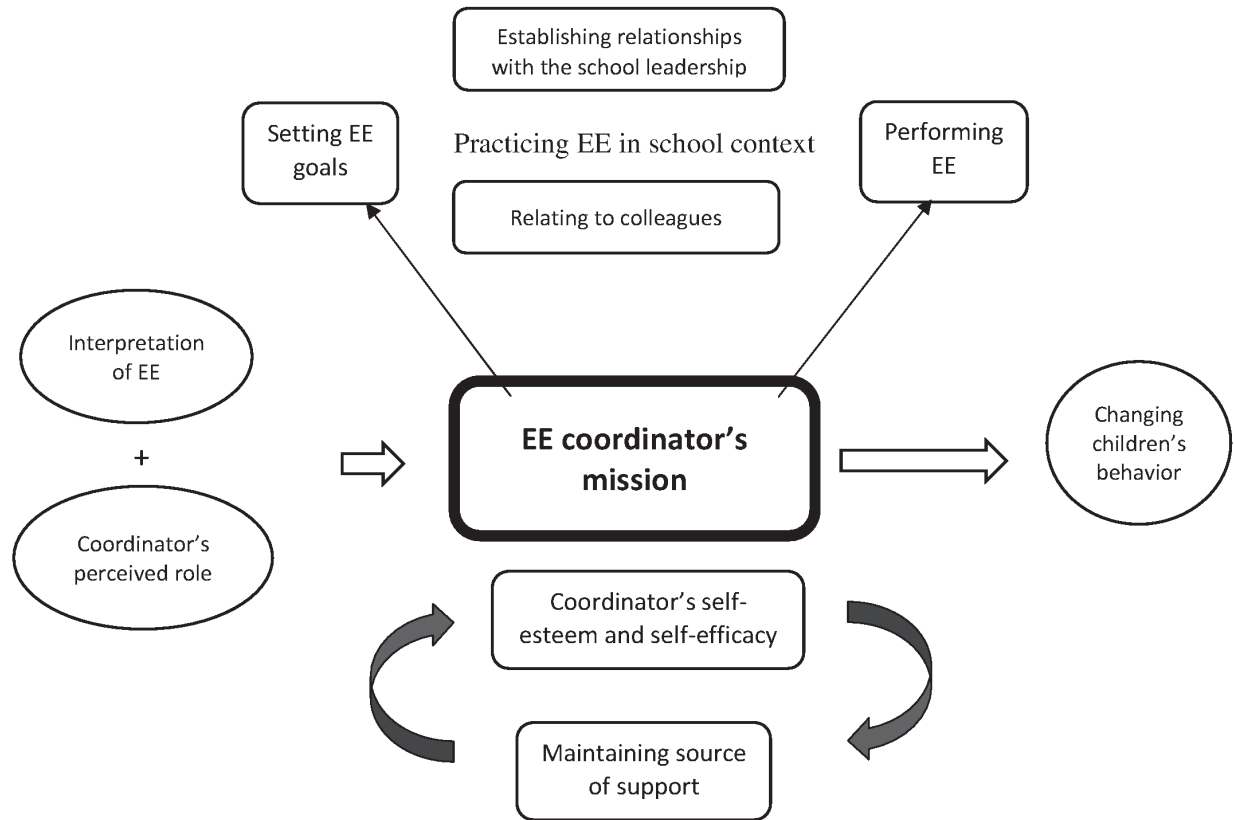

Development from unconscious and unsuccessful to conscious and successful

Figure 1. Analytical story line 
The data show a variety of the mission types connected to each participant's personality. They align the different missions on a scale from "visionary" to "pragmatist." Most of the EE school coordinators lean toward one side of the scale; there are also some coordinators who have changed their thinking about the coordinator's role and, consequently, shifted from one side on the scale to another position during their praxis.

Visionaries are coordinators who believe they can achieve major goals through EE, including those coordinators who have incorporated social responsibility into EE and who have emphasized the value orientation of EE.

It is very important to me that the school share the same values. I am quite lucky because I know my colleagues believe, like me, that we cannot abuse nature and use it selfishly.

They are also the type of people who see themselves as messengers who are not afraid to try to influence the attitudes and values of others:

And I also like, when I personally discover some truth, I rush to tell others, because I think they have to hear it immediately. I really like to communicate to other people the truth I have already accepted.

Pragmatists are coordinators who prefer concrete educational activities to achieve immediate goals. They often derive their EE ideas from environmental centers' offerings and from the actual situation at their particular school.

I read various offers from eco-centers, then choose some activities and order it for several classes. And it is successful when they like it. For example, I was satisfied, when we planted trees and nobody was hurt, the weather was nice and children enjoy the work.

They also do not perceive a need to write out plans with set goals and associated activities.

I just do not need to put it down on paper, rather we are trying to live somehow.

Whether a Visionary or a Pragmatist, the participant's mission emerges from their interpretation of EE in conjunction with their perception of the coordinators' role (see Fig. 1). Interpretation of EE asks how important EE is in itself and what are the most important aspects to achieve; perception of their role focuses on what they should do and what is not appropriate. Their mission develops over time; at the onset, the teachers do not know yet what it means to be an EE school coordinator. Their mission further develops from any situation where there is a struggle to achieve the set goals of finding more or less successful strategies on how to deal with their tasks. The vision is attaining full understanding of their role as an EE school coordinator, as well as the participation of their entire school body of faculty and students.

The individual coordinator's mission fits the particular school context and is crucially influenced by the teacher's relationship with the school leadership and the level of cooperation with colleagues. The coordinators' mission is also significantly influenced by their perceived self-esteem and self-efficacy to fulfill their role according to their expectations or the expectations of their superiors (Činčera, 2013). Furthermore, the success of the mission depends on maintaining or losing their sources of motivation, for example, whether the coordinators' training or their meeting other coordinators reaps benefits. 
Success is usually evaluated on different levels and, in some cases, by perceived success in achieving goals. For example, success may be achieved by fulfilling a set plan of environmental activities or involving colleagues in EE.

\section{The Coordinators' Perceived Role and Their Interpretation of EE}

When teachers realize they really work as EE coordinators, their perception of who is responsible for practicing EE at their school often changes. At this point, they create a mission to involve the whole school and understand EE as a holistic approach. One of the teachers describes the mission as:

This is a never-ending process of reminding, showing and explaining to everybody, making them understand that it is good to pull together and that EE is not a competition for projects or pupils' interest.

And another teacher emphasizes the relationships with colleagues:

I think one of the most important things in environmental education (especially in the coordinator's role) is to build up the relationships' network at the school, to make it functional, and to have people around who I can trust and they trust me, and who are willing to participate in environmental activities.

Obviously, for some EE coordinators, this situation is only a distant dream and they experience daily disappointment when few share their enthusiasm about changing the children's behavior to make their school more pro-environmental. Some coordinators consider themselves as EE distributors or messengers. A very common approach is to search for, order and distribute external environmental programs, which is related to the perception of EE as a mixture of activities without defined goals.

I am trying to search for environmental program offers; I also get some of them in the mail. Now I am able to tell what interests me and what does not, because when I started, I thought we should go everywhere. But now I pick some of them because I know what we liked previously and what was great, and we do it repeatedly.

Before the teachers finished their training, they were unaware of their competencies. The years after training are characterized by a gradual clarification of what an EE coordinator should do and how the communication with others should be managed. There is a difference between the coordinators who intrinsically believe in the way they work and the coordinators look for good advice from successful coordinators, as they need external acknowledgment regarding the right direction to go in EE. Some coordinators feel the need to defend their EE concepts while others feel it is easy if they believe in them themselves:

I think children learn more if they go outside of the school, they gather different experiences, see different things. I like when we teach outside of the school. Our leadership does not support it, but I stand up for the fact that it's the best... 


\section{Practicing EE in the School Context}

As mentioned above, environmental education in the Czech Republic has the status of a cross-curricular subject and teachers can choose from three implementation strategies: separate subject, integration into the curriculum, projects. The possibility to have a special subject is not only the most preferred option by most of the coordinators but also the least common one in reality given the status of EE as a cross-curricular subject. However, the coordinators call for a whole-school approach, even if they have to work within a limited timeframe for EE. They also usually use the "school EE plan" developed in the training course and consider it the foundation stone for EE implementation (see Figure 1, part Setting EE goals).

The description of the EE concept "the common things we do" corroborates that the coordinators consider organizing excursions to environmental service companies, sorting of waste at school, and arranging several events to be basic activities. They aspire to achieve more important goals; for example, EE coordinators envision developing the children's relationship with nature. Whether they understand what strategies are effective to achieve such goals remains unclear.

EE teachers always enjoy the pupils' success, and they see success in various ways. They try to let the pupils work with their hands on authentic projects such as gardening; they support the pupils' choice of activities and taking responsibility for their endeavors (see Figure 1, part Performing EE).

When we installed new benches in the garden, the pupils had to do all the work. It took a lot of time, but now they do not destroy them because they made them themselves.

The teachers also allow older pupils to teach the younger ones, preferring applied instruction in order to learn, and always emphasize the importance of the outdoors as a practical learning environment.

\section{... I think it is very important to get the children out of the school building} because nature is outside...

The teachers' colleagues, especially those who are not enthusiastic about EE, provide the most important feedback as the coordinators need to feel the appreciation of their usefulness and acknowledgment of their role. With their colleagues' psychological support, they are willing to understand the lack of interest in EE and respect their colleagues' limits as well as the collision of EE demands with other subjects' needs. The coordinators have to delineate the division of responsibilities between themselves and the school administrators, as leadership support is crucial for school-wide EE success. Unfortunately, the most common situation can be described as administrative "agreement with EE activities but not true support" (see Figure 1, part Relating to colleagues and Establishing relationships with the school leadership).

I see it depends on the leadership, whether our headmaster is willing to do it or not... at the beginning, she was not really helpful in supporting the new activities, but later she realized it is needed, and now, not that she does anything, but at least she gives the green light. 


\section{The Development of the Coordinators' Mission}

A coordinator's mission develops along with growing awareness and success. However, before the coordinator establishes his or her position in order to work successfully in the school environment, barriers must be understood and addressed, including the burnout syndrome. Establishing the coordinator's position is never a linear process; it seems to be more like swinging up and down. In the words of one teacher:

I was like a clean paper before the training, during it I was very excited, but at the same time, I bumped into all the walls. And after the training, I began slowly to work, with little successes and also failures.

Coordinators need to find a balance between their excitement to do everything amazing and to accomplish coordinating the EE process at school:

First, I had a phase when I was full of knowledge, skills, and inspiration, so of course, I wanted to churn it out to the others, but then I realized, they are not so excited, and I calmed down, clarified the priorities and goals, and I started to be successful.

On the other hand, some coordinators do not feel the need for self-development; they remain in a form of inertia and do what they have always done and what is achievable with a minimum of effort, such as booking external environmental programs, sorting of waste, and organizing traditional events such as celebrating Earth Day.

\section{The Coordinators' Self-Esteem and Self-Efficacy}

Sometimes there is a thin line between a coordinator's satisfaction and disappointment, maintained by the inner sources of motivation and outer feedback. A teacher who has completed the 250-hour training must possess strong motivation. The coordinators admit they have gained motivation for lifelong learning and constantly feel room for improvement. In general, the EE coordinators are teachers with high personal standards and a well-established habit of self-reflection; they continue to draw energy from the training even seven years later. Nevertheless, every one of them needs to have a soul mate in EE, whether another coordinator with similar problems, a colleague at school, or even an exemplary successful coordinator (see Figure 1, part Coordinator's selfesteem and self-efficacy and Maintaining source of support). Self-efficacy is evaluated by various criteria. Some coordinators include plan fulfillment or successful EE integration into subjects, some want to see the pupil's' engagement in solving environmental problems in the future.

I am still trying to move forward. It is a slow process, but I can already see some partial successes. So I see myself halfway because I think I have respect for myself as a coordinator at school and also for EE itself... I think everybody would say that EE has a significant place in the school curriculum.

In summary, the schematics of Figure 1 show the development of the EE coordinator's mission in time: before the course - after completing the course - in the longterm practice. The coordinator's mission is developed from an unconscious and unsuccessful to the conscious and successful level. The coordinators usually began implementing the EE with simple environmental activities and perceived their role more in practice 
than in planning and coordination. As they gained more complex EE interpretation, they started applying more sophisticated planning methods and setting goals aiming to change student's behavior. They also started being more and more aware of their competencies for involving the whole school environment. After some time, coordinators established their relationships with their colleagues and superiors and secured the position of EE at their school. The first successes helped them increasing their self-efficacy, and made clear with whom they may count for the further support.

\section{Discussion}

The data show that EE school coordinators believe in the importance of EE and they constantly develop their EE practice, more or less successfully. Their perception of the EE coordinators' role can be described as a mission. This mission is aligned with their behavior, acquired competencies and beliefs; it changes over time with the teachers' increased experience. A similar concept is described by Raus and Falkenberg (2014) as the teachers' ecological self, inspired by deep ecology values and beliefs.

The coordinators' mission is individually specific and includes various interpretations of EE. The research participants gave quite vague responses as to what EE includes; in their opinions, they described strategies they use rather than providing any general interpretation of EE. Such ambiguities correspond to unclear EE concepts as discussed by other EE professionals (Åhlberg, Kaasinen, Kaivola, \& Houtsonen, 2001). The teachers' responses have also underlined the complexity of EE; in particular, some teachers have stressed they want to find a way to set common goals that would be clear for everybody at their school. This kind of approach calls for a more holistic view of EE and for constructing the decisive concept according to the individual school setting (Jickling, 2007).

Nevertheless, the cornerstone of the EE concept is always related to the students and linked to the teaching strategies used by the teachers to develop the required knowledge, attitude and skills of the students. Our data resemble some of the commonly acknowledged EE goals: develop children's relationship with nature, motivate children to take care of nature or understand the local environment (Simmons, 1999). Although some teachers have highlighted the importance of supporting the children's responsibility for environmental problems, this is not widespread in the data. The situation would have been different had the teachers been trained in special programs focusing on the children's ability to solve environmental issues, as documented by Winther, Volk, and Schrock (2002).

The teachers often mentioned what barriers they face in their work as coordinators. Not surprisingly, one obstacle is a limited time schedule, especially when there is a need to involve other colleagues or to organize an event for the whole school, as well as limited financial and/or material resources. The same barriers have been mentioned in studies investigating how teachers implement new environmental education programs (Cheng \& Monroe, 2010; Kelani, 2015). This study identified different approaches: some teachers have learned how to ask for financial support while others blame the state administration for their lack of funds.

When the teachers call for an external support in EE, for example if they need an external instructor to teach their students about environmental issues, it can be seen as a lack of internal locus of control or a low level of perceived self-efficacy. The level of 
perceived self-efficacy is closely linked to self-esteem (Khan et al., 2015) and tends to be higher in women and primary school teachers (Evans \& Tribble, 1986). Kelani (2015) has shown that teachers have a high level of self-efficacy in teaching EE topics even if they are not trained in EE. In contrast, our data suggests that EE training and meeting with other coordinators support the motivation to practice quality EE. The results of this study are also consistent with the positive relationship found between teachers' sense of efficacy and their participation in decision-making in EE, and also between their motivation and the support from the school leadership (Dembo \& Gibson, 1985).

As mentioned above, the coordinators' mission develops in time, from the initial point when the coordinators do not know what they should do to the point when they consider themselves to be experienced coordinators. Experience is positively related to satisfaction with the coordinators' achievement even if, in general, the experience can be negatively correlated with the teachers' job satisfaction (Reilly et al., 2014).

This study also found a long-term positive effect of the coordinators' training on their EE practice, whereas some authors have questioned the impact of such training, especially related to the teachers' achievement (Harris \& Sass, 2011; Richardson, 1998). Therefore, we agree with Pe'er, Goldman and Yavetz (2007) that "one of the major challenges facing $\mathrm{EE}$ is to strengthen professional development for teachers, including pre-service education."

This study is limited by two aspects. First, it is based on data from the relatively small sample of teachers from one region, not a representative for all coordinators. Second, the study examines changes after one course of training, so the very interesting point of view would be offered by making a comparison with groups of coordinators who have completed the same EE training organized by different educational centers. Furthermore, the authors would like to inquire about the connection between the perceived self-efficacy of the EE coordinators and the children's achievement in several environmental variables.

\section{Conclusions}

In this study, the authors contribute to a better understanding of EE teachers' attitudes and beliefs. EE needs qualified and specialized teachers. This important role is played by EE school coordinators who not only incorporate EE into the lessons but also share their understanding of EE with their colleagues to take on leadership roles in this respect.

The authors found out that the training changed several important aspects in the participants' practice of EE, helped them developing a more complex interpretation of EE, and increased their understanding of their real competencies. As a result, it helped to improve the quality of EE in the participants' schools. Although a lot had to be overcome (e.g., the poor level of cooperation with their colleagues), the coordinators tend to perceive themselves more and more capable of performing EE. As they reflect growing students 'achievements in this field, they strengthen their belief in the importance of EE. This is what we described as "the coordinator's mission".

There is still an obvious need for special training for EE coordinators to offer assistance in overcoming all the various barriers, as well as the need for long-term support to sustain their motivation. Further research should examine the achievement of the coordinators' EE goals, especially in empowering children to work for a sustainable future. 


\section{Acknowledgments}

Authors wish to thank Martina Novotná, Master's student in the Department of Environmental Studies FSS MU for her contribution in transcription the interviews and useful comments to the text.

This article was written at Masaryk University as part of the project “Actual approaches to study environmental phenomenon" MUNI/A/1299/2014 with the support of the Specific University Research Grant, as provided by the Ministry of Education, Youth and Sports of the Czech Republic in the year 2014.

\section{References}

Åhlberg, M., Kaasinen, A., Kaivola, T., \& Houtsonen, L. (2001). Collaborative knowledge building to promote in-service teacher training in environmental education. Journal of Information Technology for Teacher Education, 10(3), 227240. http://doi.org/10.1080/14759390100200113

Bandura, A. (1977). Self-efficacy: toward a unifying theory of behavioral change. Psychological Review, 84(2), 191-215. http://doi.org/10.1037/0033-295X.84.2.191

CENIA (2015). O environmentálním vzdělávání, výchově a osvětě. [About environmental education] Retrieved October 16, 2015, from http://www1.cenia.cz/www/evvo/ o-evvo

Činčera, J. (2013). Managing cognitive dissonance: experience from an environmental education teachers' training course in the Czech Republic. Journal of Teacher Education for Sustainability, 15(2), 42-51. http://doi.org/10.2478/jtes-2013-0010

Činčera, J., Gilar, P., \& Sokolovičová, J. (2010). Specializační studium pro koordinátory environmentální výchovy, vzdělávání a osvěty: interpretace a efektivita z pohledu absolventů. [Teacher's training for environmental education school coordinators: interpretation and effectivity from the perspective of graduates]. Envigogika Charles University E-Journal for Environmental Education, 1-20.

Dembo, M. H., \& Gibson, S. (1985). Teachers' sense of efficacy: An important factor in school improvement california. The Elementary School Journal, 86(2), 173184.

Evans, E., \& Tribble, M. (1986). Perceived teaching problems, self-efficacy, and commitment to teaching among pre-service teachers. Journal of Educational Research, $80(2), 81-85$.

Evers, W. J. G., Brouwers, A., \& Tomic, W. (2002). Burnout and self-efficacy: A study on teachers' beliefs when implementing an innovative educational system in the Netherlands. British Journal of Educational Psychology, 72(2), 227-243. http://doi.org/10.1348/000709902158865

Harris, D. N., \& Sass, T. R. (2011). Teacher training, teacher quality and student achievement. Journal of Public Economics, 95(7-8), 798-812. http://doi.org/ 10.1016/j.jpubeco.2010.11.009

Higgs, A. L., \& McMillan, V. M. (2006). Teaching through modeling: Four schools' experiences in sustainability education. The Journal of Environmental Education, 38(1), 39-53. http://doi.org/10.3200/JOEE.38.1.39-53

Charmaz, K. (2006). Constructing grounded theory: A practical guide through qualitative analysis. London: SAGE. http://doi.org/10.1016/j.lisr.2007.11.003 
Cheng, J. C.- H., \& Monroe, M. C. (2010). Examining teachers' attitudes toward a required environmental education program. Applied Environmental Education \& Communication, 9(1), 28-37. http://doi.org/10.1080/15330150903566463

Jickling, B. (2007). If environmental education is to make sense for teachers, we had better rethink how we define it! Canadian Journal of Environmental Education (CJEE), 86-103. Retrieved April 1, 2016, from http://cjee.lakeheadu.ca/index.php/ cjee/article/view/355

Kelani, R. (2015). Integration of environmental education in science curricula in secondary schools in Benin, West Africa/: Teachers' perceptions and challenges. Electronic Journal of Science Education, 19(3).

Khan, A., Fleva, E., \& Qazi, T. (2015). The role of self-esteem and general self-efficacy in teachers' efficacy in primary schools. Psychology, 06(01), 117-125. http://doi.org/ 10.4236/psych.2015.61010

Kyburz, Graber, R., \& Robottom, I. (1999). The OECDENSI project and its relevance for teacher training concepts in environmental education. Environmental Education Research, 5(3), 273-291. http://doi.org/10.1080/1350462990050303

May, T. S., \& Flack, J. a. (2001). Do we need more "trained" teachers? The Journal of Environmental Education, 32(4), 5-7. http://doi.org/10.1080/00958960109598656

Moseley, C., Reinke, K., \& Bookout, V. (2002). The effect of teaching outdoor environmental education on preservice teachers' attitudes toward self-efficacy and outcome expectancy. The Journal of Environmental Education, 34(1), 9-15.

MSMT (2008). “Metodický pokyn MŠMT k zajištění environmentálního vzdělávání, výchovy a osvěty (EVVO)" [Methodological guidelines Ministry of Education for implementing EE at schools]. Retrieved June 19, 2015, from http://www.msmt.cz/ vzdelavani/zakladni-vzdelavani/metodicky-pokyn-msmt-k-zajistenienvironmentalniho.

Pe'er, S., Goldman, D., \& Yavetz, B. (2007). Environmental literacy in teacher training: Attitudes, knowledge, and environmental behavior of beginning students. The Journal of Environmental Education, 39(1), 45-59. Rerieved May 1, 2015, from http://doi.org/10.3200/JOEE.39.1.45-59

Pipere, A., Veisson, M., \& Salīte, I. (2015). Developing research in teacher education for sustainability: UN DESC via the Journal of Teacher Education for Sustainability. Journal of Teacher Education for Sustainability, 17(2), 5-44.

Raus, R., \& Falkenberg, T. (2014). The journey towards a teacher's ecological self: A case study of a student teacher. Journal of Teacher Education for Sustainability, 16(2), 103-114. Retrieved June 1, 2015, from http://doi.org/10.2478/jtes-20140014

Reilly, E., Dhingra, K., \& Boduszek, D. (2014). Teachers' self-efficacy beliefs, selfesteem, and job stress as determinants of job satisfaction. International Journal of Educational Management, 28(4), 365-378. Retrieved May 1, 2015, from http://doi.org/10.1108/IJEM-04-2013-0053

Richardson, V. (1998). How teachers change. What will lead to change that most benefits student learning? Focus on Basic. Connecting Research and Practice, 2.

Saldana, J. (2009). The coding manual for qualitative researchers. The coding manual for qualitative researchers. London: SAGE.

Schelly, C., Cross, J. E., Franzen, W., Hall, P., \& Reeve, S. (2012). How to go green: Creating a conservation culture in a public high school through education, modeling, 
and communication. The Journal of Environmental Education, 43(3), 143-161. Retrieved May 1, 2015, from http://doi.org/10.1080/00958964.2011.631611

Simmons, B. (2010). Guidelines for the preparation and professional development of environmental educators. The North American Association for Environmental Education. Retrieved May 5, 2015 from https:/naaee.org/eepro/publication/ guidelines-preparation-and-professional-development-environmental-educators

Simmons, D. (1999). Excellence in environmental education: Guidelines for learning (K-12). North American Association for Environmental Education. Retrieved April 1, 2016, from https://naaee.org/eepro/publication/excellence-environmentaleducation-guidelines-learning-k-12

Strauss, A., \& Corbin, J. (2008). Basics of qualitative research: Techniques and procedures for developing grounded theory. Basics of qualitative research grounded theory procedures and techniques, 3 Retrieved May7, 2015, from http://doi.org/10.4135/ 9781452230153

Świtala, E. (2015). Teachers' values related to sustainable development in Polish and Latvian secondary schools. Discourse and Communication for Sustainable Education, 6, 127-131. Retrieved April 1, 2016, from: http://doi.org/10.1515/dcse-20150009

Šed'ová, K., \& Švaříček, R. (2007). Kvalitativní výzkum v pedagogických vědách [Qualitative research in pedagogy]. Praha: Portál.

Van Petegem, P., Blieck, A., Imbrecht, I., \& Van Hout, T. (2005). Implementing environmental education in preservice teacher training. Environmental Education Research, 11(2), 161-171. Retrieved April 1, 2016 from http://doi.org/10.1080/ 1350462042000338333

Winther, A. a., Volk, T. L., \& Shrock, S. a. (2002). Teacher decision making in the 1st year of implementing an issues-based environmental education program: A qualitative study. The Journal of Environmental Education, 33(3), 27-33. Retrieved May 1, 2016 from http://doi.org/10.1080/00958960209600812

Correspondence concerning this article should be addressed to Petra Šimonová, Department of Environmental Studies, Faculty of Social Studies, Masaryk University, Brno, Joštova 10, 60200 Brno, Czech Republic. Email: simonova@mail.muni.cz, simonova.tereza@gmail.com 